\title{
The Role of Advertising in the Organization of Digital Marketing Concept
}

\author{
Hassan Ali Al-Ababneh ${ }^{1, *}$ Nazarov A.D. ${ }^{2}$ Kondratenko I.S. ${ }^{2}$ \\ ${ }^{1}$ Irbid National University, Irbid, Jorda \\ ${ }^{2}$ Ural State University of Economics, Yekaterinburg, Russia \\ *Corresponding author. Email: hassan_ababneh@inu.edu.jo
}

\begin{abstract}
The article considers theoretical aspects of the use of advertising in the framework of marketing in modern conditions. The relevance and conceptual necessity of highlighting the main role of advertising in the concept of Internet marketing of organizations in modern conditions are determined. The main theoretical aspects of the use of advertising as an element of the marketing complex are analyzed, which allowed the author to determine the conceptual need for the classification of existing types of advertising. Since in the theory of marketing there is no single approach to determining the main role of advertising, its essence, main types and use in the marketing mix, the author proposes the classification of advertising depending on the areas of its use. The modern types of advertising in the framework of the Internet marketing concept of an organization were structured, the main goals, objectives and key functions of advertising in the modern conditions of the global market transformation are formed. A theoretical substantiation of the key role of advertising in the framework of the organization's Internet marketing concept has been carried out, the main types of advertising have been structured with a description of their characteristics, advantages, and disadvantages of use in modern conditions.

It is proved that the formation of the concept of Internet marketing is impossible without the use of innovative tools to promote goods and services such as advertising. The main trends in the development of the advertising market in the world were studied. The structure of the global advertising market for its key types, which are used in the concept of online marketing of organizations, is analyzed, and their average profitability (ROI,\%) is analyzed in terms of tools, which confirmed the theoretical justification of the main role of advertising in the concept of online marketing of organizations, since the effective use of modern tools for promoting goods and services allows optimizing the level of expenses and ensures the growth of strategic financial indicators.
\end{abstract}

Keywords: concept, marketing complex, Internet marketing, marketing elements, marketing strategy, market, product, price, risk, efficiency

\section{INTRODUCTION}

In modern conditions, doing business is unthinkable without the use of information technologies, which are widely used in the concept of Internet marketing and its main elements in the form of advertising, PR campaigns that are aimed at improving the image of any organization. Doing business in modern conditions determines the main strategic priorities for the development of organizations that are aimed at strengthening competitive positions in the market by involving the maximum number of consumers of goods and services, reducing costs and optimizing income of organizations through the effective use of elements containing the concept of Internet marketing. Particular attention in the current conditions of the functioning of organizations is given to such an element of the concept of Internet marketing as the promotion of goods and services (advertising, PR campaigns) on which the image and level of the marketing organization, which ensures competitive position, consumer recognition and trust in the market, increase the level of sales and cost optimization. The increasing role of advertising in modern business has led to increased interest in the study of this social phenomenon among scientists from different fields of science.

To highlight the main role of advertising in the concept of Internet marketing, it is advisable to analyze the theoretical aspects and research in the framework of the 
problems of this topic. It is worth noting that a group of scientists such as: M. Isoraite (2016) [1], Alakidy Beniyan F.Ibrahem (2012) [2], Dobrikova T.S. (2012) [3], L. Nersisyan (2016) [4], Vella L., Kester J. ( 2009) [5], McCharty EJ (1965) [6], Meffert, H. (2000) [7], Chaffey D., Ellis-Chadwick F., Mayer R., Johnston K. (2006) [8] distinguish advertising as the main element of marketing and the conceptual need for its use as a tool for building relationships with consumers, identifying the target segment and promoting goods and services. It should be noted that these approaches determine the main subjects and objects of these relations, but do not determine the conceptual approaches to organizing the concept of Internet marketing on the basis of using advanced types of advertising. In contrast to the approach presented above, a group of scientists: Boyev E. I. (2005) [9], Yuldasheva O.U. (2004) [10],

Mukhtasarov A. F. (2017) [11], Kotler F.K (2009) [12], Alleman, J., Rappoport, P. (2007) [13], Kanishcheva T.D., Golovaneva I.I., Filatova N .I. (2014) [14], Hollensen S. (2010) [15], Rogozhin M.Yu. (2010) [16] determine the main goals of advertising, which are aimed at attracting the attention of the audience to the object of advertising and the formation of a positive image and the preferred choice of goods and services. This approach reveals the main essence, goals, and objectives of advertising, but does not consider advertising as a key element of the concept of Internet marketing, which in modern conditions affects the formation of strategic guidelines for the development of the organization and requires further research. Advertising as the main element of the marketing complex considered by a group of scientists such as: Breton F. (2007) [17], Berdnikov I.P. (2017) [18], Nuremberber L. B., Karuleva E. A (2008) [19],

Safarova M.B. (2015) [20], Kononenko N.V. (2008) [21], Moiseenko I.V. (2011) [22], which highlight the need to include "4P" promotion of goods and services (advertising) in the marketing mix. It is worth noting that this approach is not adapted to the current conditions for the functioning of organizations, since the formation of a marketing concept, taking into account the intensive development of innovative technologies, is quite flexible and dynamic and includes a large number of elements.

A special contribution to the study of the basic conceptual approaches to the use of advertising and PR campaigns as the main elements of marketing an organization in modern conditions was made by a group of the following scientists: Mazilkina E.I. (2012) [23], Kononov V.O. (2016) [24], Otlacan, O. (2005) [25], Mansurov R.E. (2011) [26], Pastore A., \& Vemuccio M. (2004) [27], Burtseva T.A. (2004) [28], Ikaeva R.V. (2012) [29], Khrutsky V.E. (2002) [30], Kardapoltsev K.V. (2015) [31], Ryumin M. Yu. (2016) [32], Melentyev N.I. (2007) [33], Burnet J., Moriarty S.
(2001) [34], Vekshinsky A. (2012) [35], Grokhovsky L. Sevostyanov I., Ivanov D., (2015) [36], Teletov A.S. (2015) [37],

Hershgen H. (2000) [38], the consolidation of the main results of their research allows us to determine that the use of advertising and PR campaigns as the main elements of an organization's marketing are considered to be the revolutionary and most promising form of organizing marketing activities. However, according to the results of these studies, it is worth noting that there is no single approach to the use of advertising within the framework of the marketing concept, which allows us to conclude the feasibility of further research.

The scientific research of the following group of scientists: Tyurina S. Yu. (2009) [39], Doskova I.S. (2004) [40], Krylov A., Zuenkova O. (2006) [41], Smirnov A.Yu. (2015) [42], Alashkin P. (2009) [43], Panin K.G. (2010) [44], Godin A.A., Godin A.M.,

Komarov V.M. (2009) [45], Spiridonova G.V. (2017) [46], Tulupov V.V. (2011) [47], T. Kegler are devoted to classifications of types of advertising and its use in modern conditions for the formation of organizations' Internet marketing concepts . Dowling P. Taylor B. Testerman D. (2003) [48]. The main aspects of the formation of advertising as an element of marketing and its use in modern marketing concepts are considered in these works, however, despite the significant contribution of scientific research by both domestic and foreign scientists to areas of the theory of the advertising use in the formation of the marketing complex of an organization, there are many pressing issues that explain the relevance of this topic and the need for a more detailed and in-depth study. Regardless of the existing approaches to the study of advertising, as a key element of marketing, most modern researchers to some extent relate to the communicative aspects of advertising, its premises or the main goal, which requires further systematization of these views, classification of existing types of advertising and structuring of its basic elements, which determines the need to highlight the key role of advertising in the concept of the Internet marketing organization in modern conditions.

Transformation processes in the global economy determine the top management of organizations to apply the most effective marketing methods and tools to ensure competitive positions in the market, promote goods and services in order to reduce costs and optimize financial results. It should be noted that one of the main and most effective marketing tools in modern conditions is advertising, which is a containing element of the concept of Internet marketing, which the organization forms based on its strategic goals and development initiatives .. 


\section{ANALYSIS OF LATEST RESEARCHES AND PUBLICATIONS}

The conceptual need for the effective use of the concept of Internet marketing in modern business conditions is one of the most basic directions and strategic initiatives. An effective concept of an organization's Internet marketing largely depends on the rational use of key elements containing it, with which strategic indicators are achieved and competitive market positions are provided by increasing sales volumes using modern types of marketing promotion of goods and services such as advertising and PR - company. To determine the main role of advertising in the concept of Internet marketing of an organization in modern conditions, it is necessary to consider the main existing approaches to determining the definition of advertising and its use in the marketing mix. According to famous marketer F. Kotler (2009) [12, p. 96], advertisement is any paid form of non-personal presentation and promotion of ideas, goods and services of a specific customer or manufacturer. This interpretation reveals the main functions of advertising, but does not take into account its key role in the concept of Internet marketing in modern conditions, which is based on the use of innovative technologies and techniques for promoting goods and services.

A group of scientists of Kanishcheva T.D., Golovaneva I.I., Filatova N.I. (2014) [14, p. 348], who investigated the theory of the functioning of advertising, define it as an impersonal commercial form of disseminating information about the properties of goods and services that are useful and necessary for consumers, which in its turn reveals the basic need for advertising, but does not specify with what tools, which is very important to consider in modern conditions of the formation of the concept of the Internet marketing organization. The idea of Wells W., Burnet J., Moriarty S. (1999) [49, p. 266] defines advertising as a paid, not personalized communication carried out by an identified sponsor with using the media to persuade (in something) or influence (somehow) the audience. The proposed idea reveals the main purpose of advertising, but not the features of its application, as the main containing element of the concept of Internet marketing in modern conditions. Thus, N.V. Kononenko considers that advertising is the information about a legal or physical person distributed in any form, by any means, or about product, idea or event (advertising information), which is intended for an indefinite number of persons and is designed to form and maintain interest in the product and contribute to the implementation of goods, ideas and events (2008) [21, p. 73]. It should be noted that this idea, being closer to modern realities, reveals a more precise essence of advertising as an information component of the marketing complex, which in modern conditions is not enough to ensure competitive positions in the market.

In modern conditions of the global market transformation, the effectiveness of the organization's functioning depends on the formed concept of Internet marketing, which is based on the main elements of the marketing complex and the use of advanced technologies to maximize financial results and expand competitive positions in the market. Thus, it is worth noting that advertising should be a key component of the organization's Internet marketing concept, which ensures the effective promotion of goods and services on the market using innovative tools and methods for conducting PR-companies. Since the disunity in the definition of advertising and the lack of a unified approach to the classification of its main types and basic tools, which are based on innovative technologies for promoting goods and services and highlighting the main role of advertising in the concept of Internet marketing of an organization, determine the conceptual need for further in-depth research.

\section{UNSOLVED PARTS OF THE PROBLEM}

The considered main aspects of the theory of marketing and its containing element of the promotion of goods and services (advertising) made it possible to determine the need for concretization of the main role of advertising in the concept of Internet marketing of an organization in modern conditions. The transformation processes of the world market determine the conceptual need to highlight advertising and PR-companies as key containing elements of marketing.

The modern market is characterized by the intensive penetration of information technologies and innovative tools that increase the level of competition, which in its turn necessitates the conquest of a part of the market by promoting goods and services through advertising, which is a key element of the concept of Internet marketing. To study the main role of advertising in the concept of Internet marketing of an organization in modern conditions, the basic concepts of advertising and its use in the marketing mix should be structured. It should be noted that there is a need for the classification of existing types of advertising and its use in the concept of the Internet marketing organization. It should also be noted that special attention is required to study the influence of the main global trends in advertising on the concept of Internet marketing of an organization and its key elements. The use of innovative technologies and tools is quite relevant in modern condition and leads to the improvement of existing types of advertising and its main tools, which have a significant impact on the final results of the organization's Internet marketing concept causing an additional need for more in-depth research.

\section{PURPOSE OF THE STUDY}

The theoretical justification of the role of advertising in the concept of Internet marketing organization, the structuring of existing types of advertising and PR-companies in modern conditions.

The goal of the study identified the tasks that should be solved in the study: analysis of the theoretical aspects of 
the development of advertising as an element of the marketing mix; classification of existing types of advertising of PR-companies, the use of innovative Internet technologies in the world and their use in advertising; conceptualization of the main role of advertising in the concept of Internet marketing; formation of theoretical recommendations on improving tools for promoting goods and services within the framework of the concept of Internet marketing of an organization in modern conditions.

\section{MATERIALS AND METHODS}

The theoretical basis of the study is the fundamental provisions of the marketing modern theory and its containing elements. In the framework of the study, both general scientific and special methods of cognition were used: analysis and synthesis - to develop theoretical recommendations for improving the tools for promoting goods and services within the framework of the organization's Internet marketing concept in modern conditions; theoretical generalization - in determining the essence of advertising and its basic tools; graphical method - when analyzing the development of the advertising market in the world and estimating advertising costs in the financial sector.

The research information base was the key data of the World Bank, the International Bank for Reconstruction and Development, the International Monetary Fund, the International Finance Corporation, Internet resources in the framework of marketing research and communications, scientific works of domestic and foreign scientists, economists, marketers, etc.

\section{BASIC STUDY RESULTS}

An important role in the marketing complex of an organization in modern conditions is played by marketing communications. The main task of marketing communications can be represented as a message and the media aimed at transmitting information about a product or service and establishing links with the target audience, industry, market. Modern marketing concepts are quite flexible and dynamic and include a wide range of key elements such as price, product, advertising, brand, public relations, customer focus, sales promotion, personal sales, loyalty programs, and sponsorship. However, special attention should be paid specifically to advertising, since it performs the main function of marketing communications, being a connection that transfers from the advertiser to the target audience in order to inform the consumer as much as possible about the product or service in order to further stimulate it to buy. The main functions of advertising within the framework of the organization's Internet marketing concept are shown in Figure 1.

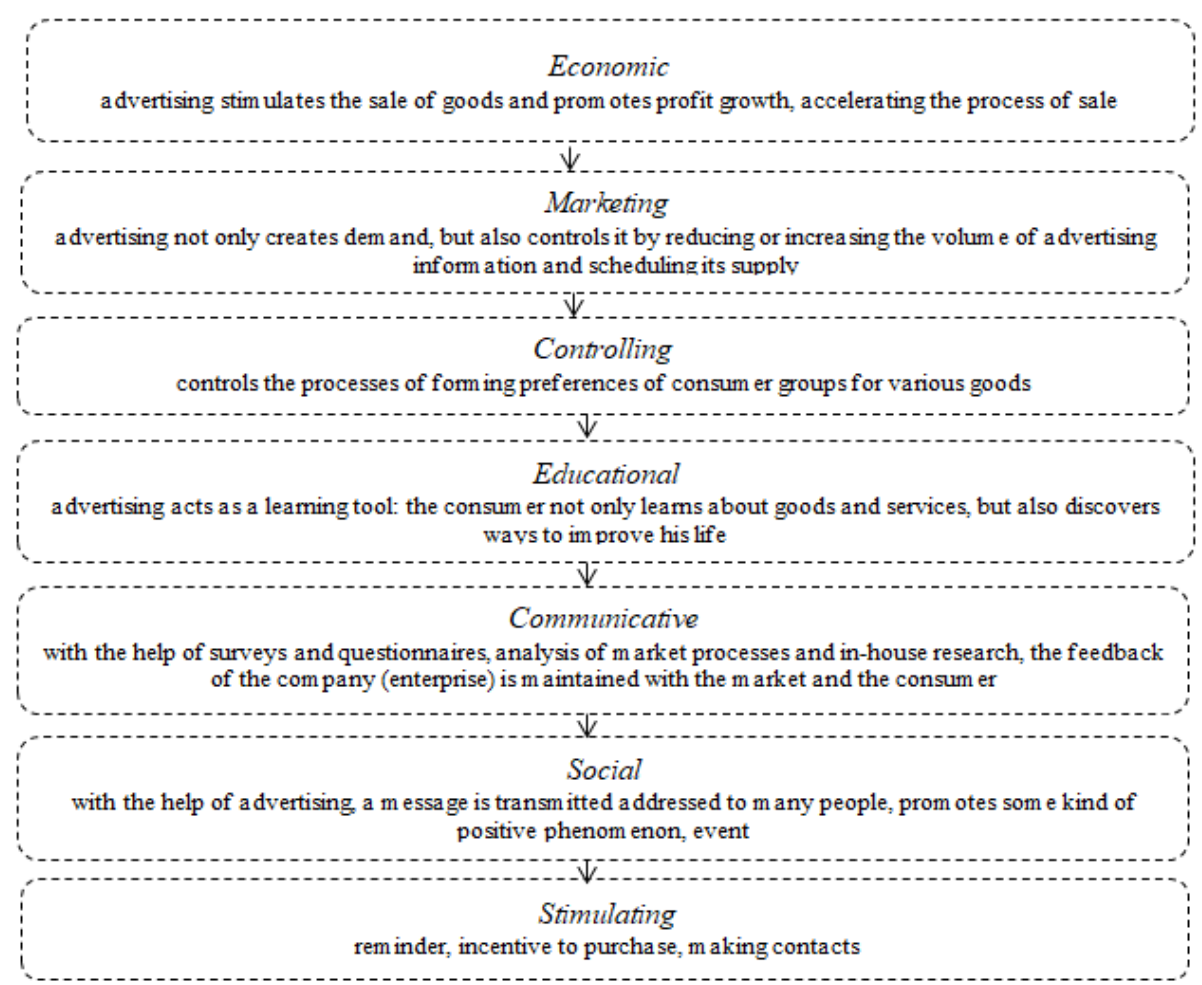

Figure 1 The main functions of advertising in the framework of the Internet marketing organization concept [6, 9-10]

It should be noted that marketing is the basis for organizing the process of marketing products, promoting new products to the consumer, developing a strategy for advertising these products and services. Marketing methods for sales stimulation and increasing competitive positions in the market are based on the organization's 
activity in disseminating information about the merits of its product and convincing target consumers to buy it using such a marketing element - advertising as the main form of communication. The functioning of organizations and the formation of the Internet marketing concept in which advertising is always aimed at the consumer, including potential, it aims to inform him in various ways about new goods and services and their consumer properties. The goals of the organization's advertising activities should be clearly established, quantified and determined by the terms, which will allow controlling the effectiveness of advertising as an element containing the concept of Internet marketing. The main goals and objectives of advertising as a containing element of the concept of Internet marketing organization in modern conditions are presented in Figure 2.

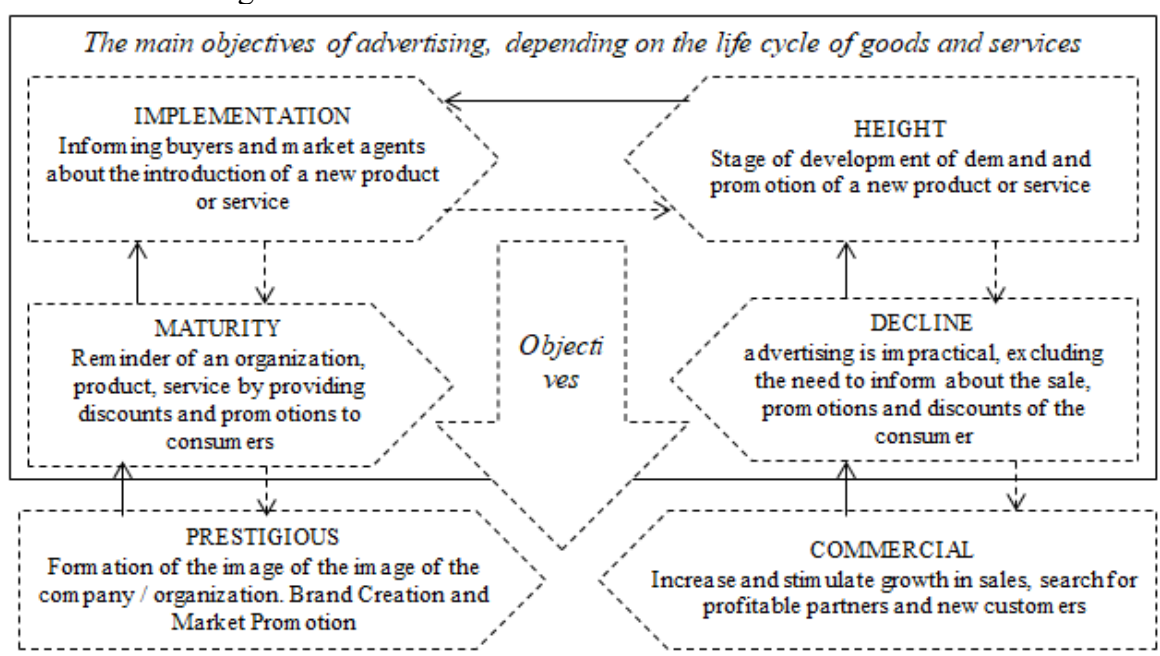

Figure 2 The main goals and objectives of advertising in the framework of the concept of Internet marketing organization $[14,16]$

To achieve the goals and objectives of advertising within the framework of the formed concept of the organization's Internet marketing in modern conditions, the instrument of advertising and PR companies or their combination that most closely matches the set requirements and strategic

Table 1 Classification the areas of advertising use as a key element of the concept of internet marketing

\begin{tabular}{|l|l|}
\hline Advertising field & The main subject area for advertising \\
\hline Economy & Production, trade, finance, labor supply, job searches \\
\hline Domestic services & Repair, sewing, manufacturing of household items, recreation. \\
\hline Intellectual services & Education, medicine, books, press, fortune-telling, tourism. \\
\hline Events & Circus, theater, concert \\
\hline Religion & Religious posters, invitations. \\
\hline Politics & $\begin{array}{l}\text { Campaigning for candidates in elections, slogans of rallies, demonstrations, } \\
\text { processions. }\end{array}$ \\
\hline Law & Reporting the missing, searching for criminals, invitations to litigation. \\
\hline Science and ecology & $\begin{array}{l}\text { Enlightenment advertising, scientific popularization in leaflets, posters, leaflets, } \\
\text { booklets. }\end{array}$ \\
\hline $\begin{array}{l}\text { Family and interpersonal } \\
\text { relationships }\end{array}$ & Marriage announcements, invitations to meet, travel together, joining to business. \\
\hline Charity & Announcement about charity events, appeals for donations \\
\hline
\end{tabular}

initiatives are selected. Advertising is a powerful element of the concept of Internet marketing since it covers many areas of activity, which are presented in Table 1.

Source: Compiled by the author based on [19-25]

In modern literature, the concept of advertising as containing an element of the Internet marketing concept has a double meaning: it can mean advertising as a product (this is what is provided to consumers of goods and services) or as a manufacturing process of this product. Given the need to understand advertising as one of the main tools and containing elements of the organization's Internet marketing concept, we consider it necessary to 
advertising. Therefore, in order to justify the role of advertising in the concept of the organization's Internet marketing, for practical use, it is necessary to classify advertising and its main types and tools as the basis, which is based on a sign of the correspondence of advertising media to advertiser types shown in Figure 3. supplement the interpretation of advertising as participating in the production and sale of products and services. Advertising (as a product) is the visual consumer perception of advertising messages and publications in order to perform a communication function. Advertising (as a product creation process) is an advertising product that should attract consumer attention and increase their share by performing the informational function of

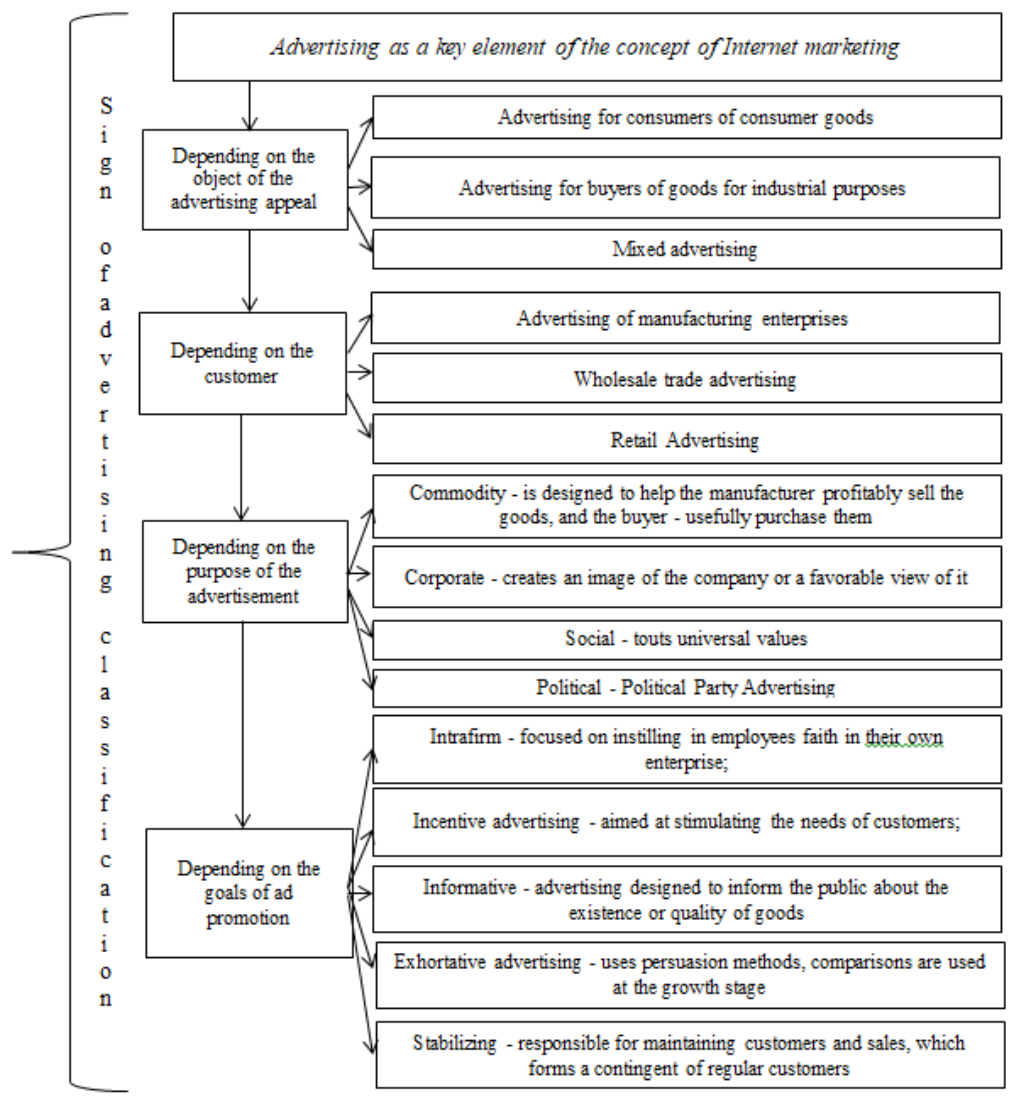

Figure 3 Classification of advertising as a key containing element of the Internet marketing organization concept [14, 16]

A high level of competition in the markets makes it possible to use various types of advertising and promotion of goods and services for conducting business for effective positioning and promotion. The formation of the optimal concept of the organization's Internet marketing, which defines the goals and development strategy in the market, and the use of modern types of advertising and PRcompanies provides for quick and effective reaching the target audience. The main types and directions of advertising within the framework of the organization's Internet marketing concept are presented in Figure 4. 


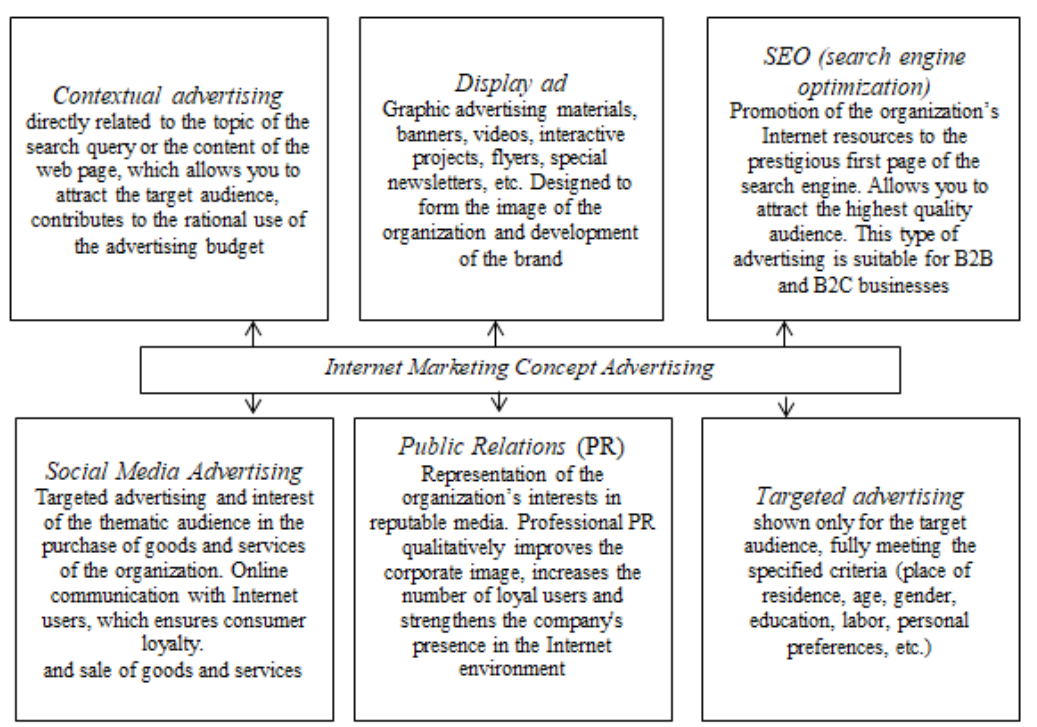

Figure 4 The main types and directions of advertising in the framework of the concept of Internet marketing organization $[29,30,48]$

The concept of Internet marketing involves the use of advertising in combination with innovative Internet technologies allowing reliable targeting of the consumer audience and the promotional materials supplying. The effectiveness of complex events is much more tangible than the potential return of individual marketing processes. This effect is called synergy, when the interaction of several areas provides an excellent result, significantly

exceeding the simple summation of achievements in individual areas. High flexibility of the concept of Internet marketing and the effectiveness of all types of advertising will be useful for the formation and development of any organization. The dynamics of the advertising share in the concept of Internet marketing of organizations in the world for the period from $01 / 01 / 2010$ to $01 / 01 / 2019$ in $\%$ is presented in Figure 5.

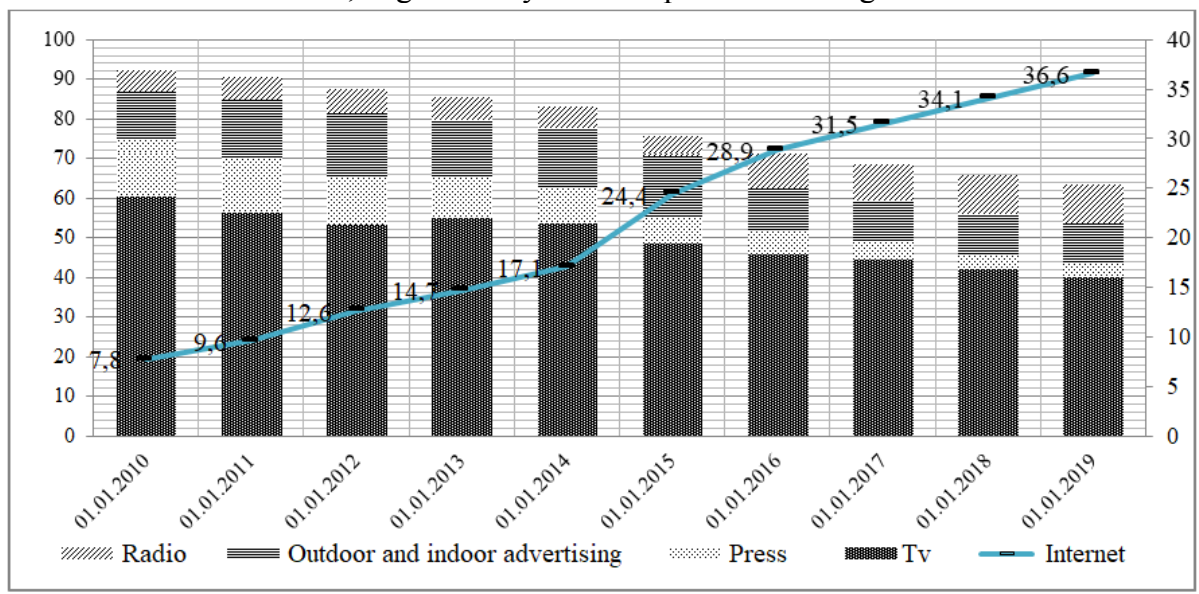

Figure 5 Dynamics of the advertising share in key media resources of the world for the period from 01/01/2010 to $01 / 01 / 2019, \%[51]$

Figure 5 shows that advertising is used in all possible media channels for communication, promotion of goods and services, and market positioning. For the period from $01 / 01 / 2014$ to $01 / 01 / 2019$, the largest share of advertising belongs to the Internet, which allows realizing the speculative goals of the organization by increasing sales, increasing customer loyalty and market recognition. The use of advertising in the concept of Internet marketing entails a rather huge amount of expenses of the organization, which depend on the chosen type of advertising. Dynamics of key indicators of advertising market volumes in the world, contribution of types of advertising to the growth of global advertising costs in the world, in billion of dollars and the ratio to GDP indicators are presented in Figure 6. 

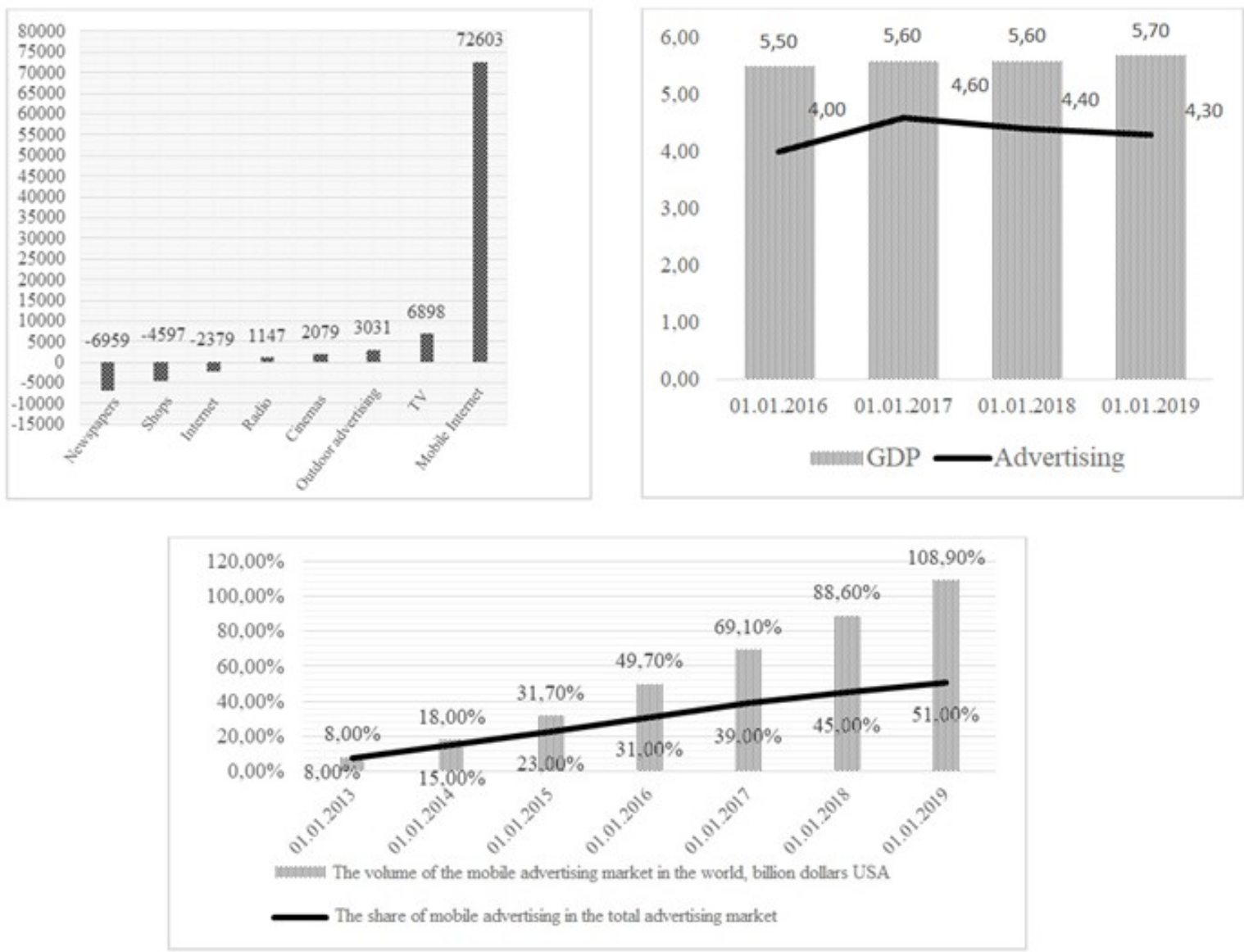

Figure 6 The dynamics of key indicators of the advertising market volume in the world, the contribution of types of advertising in the growth of global spending on advertising in the world, in billion of dollars and the ratio to GDP [51]

The presented dynamics of the advertising main uses contribution in the world indicates that the most popular are the most used innovative types of advertising using Internet resources, which can optimize the structure of advertising costs and increase the volume of its promotion, allowing attracting consumers and their loyalty to the goods and services of the organization. The dynamics of GDP in the world indicates that the level of advertising that is used to formulate the concept of Internet marketing of organizations is dependent on it, which indicates the fluctuation of data on the $\%$ ratio of advertising to GDP. To justify the key role of advertising in the concept of Internet marketing of organizations, it is necessary to consider the share of growth in advertising using Internet technologies, their profitability in the context of the main types that are used in the marketing mix in world business practice. The structure of the global advertising market and its profitability as of $01 / 01 / 2019$ in $\%$ are presented in Figure 7. 

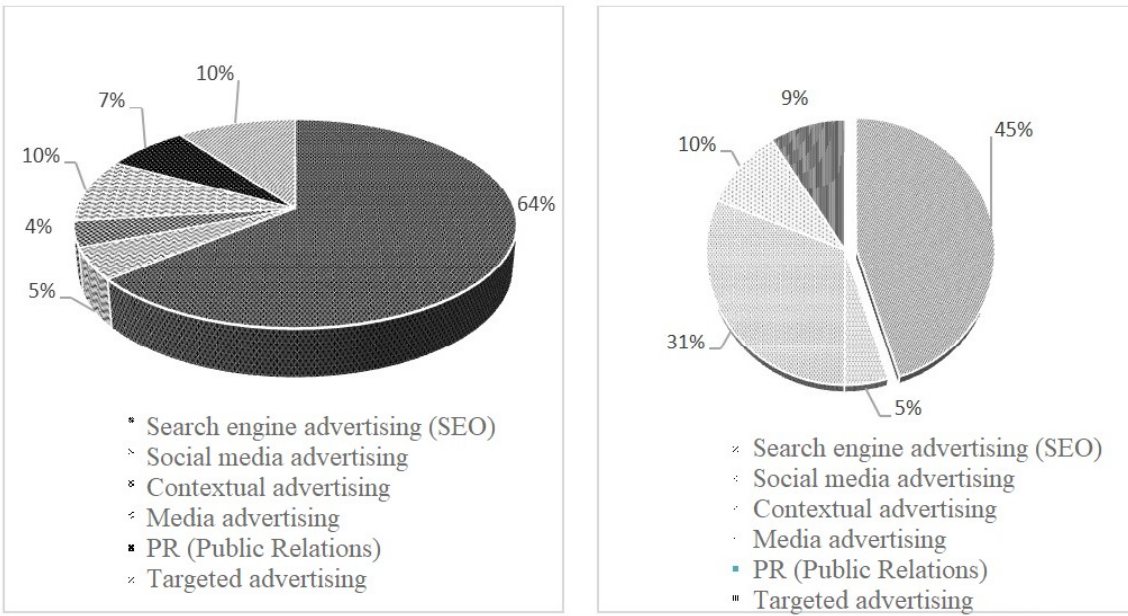

Figure 7 The structure of the global advertising market and its average return (ROI,\%) as of 01.01.2019 in\% [51]

The presented structure of the advertising market in the world and its average profitability in Fig. 7 indicates the significant role of advertising in the promotion of goods and services as the main containing element of the concept of the Internet marketing organization. The largest share in the structure of advertising types belongs to advertising using Internet technologies: Search advertising (SEO), display advertising, contextual advertising with a share in the world market of over $70 \%$. It allows us to state the fact that the formation of a modern concept of Internet marketing is impossible without applying advanced technologies and innovative mechanisms for promoting goods and services.

\section{CONCLUSIONS}

In the study, the author examined the main theoretical aspects of the formation of marketing and the use of advertising in its complexity as a key containing elements in modern conditions. An in-depth theoretical and methodological analysis of scientific research in the field of the use of advertising in the concept of Internet marketing was carried out, which made it possible to determine the relevance and urgent need to improve existing approaches to determining the role of advertising in the concept of online marketing of an organization in modern conditions.

The lack of a unified scientific approach to the classification of advertising as a key element of the concept of the organization's Internet marketing led to the structuring of advertising types. The author has developed the theoretical aspects of the formation of the Internet marketing organization concept using modern types of advertising to promote goods and services on the market. The paper presents a classification of the main types of advertising as containing elements of the Internet marketing concept with a description of their characteristics, features of use in different industries with the justification of its advantages and disadvantages. The analysis of the share of advertising in key media resources of the world was carried out. The key role of advertising using modern information and Internet technologies has been determined, which allows increasing business profitability, customer loyalty and winning the target audience.

It is taught that the use of advertising in the concept of Internet marketing of world organizations increases the level of competitiveness of an organization, recognizability of a company and brand, providing a competitive position in the market. The analysis of the advertising market structure in the world is carried out, it is determined that the largest part of the market is occupied by innovative types of advertising, such as search advertising (SEO), display advertising, contextual advertising with the share in the world market of more than $70 \%$, the use of which, in the relation to Internet marketing organizations, leads to costs optimization for the promotion of the goods and increasing target financial indicators.

\section{REFERENCES}

[1] M. Isoraite. Marketing mix theoretical aspects. International Journal of Research - Grantha- alayah, Vol. 4, №. 6 (2016), 25-27 p.

[2] Alakidy Beniyan F.Ibrahem. Electronics marketing and its impact on the quality of banking services in Iraqi commercial banks / Beniyan F.Ibrahem Alakidy, 2012. - 10p.

[3] T.S. Dobrikova, A.M. Kovaleva, Rol' reklamy v sovremennom obshchestve//Molodoy uchenyy- 2012№12, -201-213 s.

[4] L.K. Nersisyan, Imidzh organizatsii kak ob"yekt upravleniya i instrument konkurentnoy strategii // Ekonomika regiona: novyye vyzovy sbornik nauchnykh statey po materialam mezhdunarodnoy nauchno-prakticheskoy konferentsii, 2016- S. 126-130. 
[5] L. Vella, J. Kester, Handbook on e-marketing for tourism destination / World Tourism Organization and the European Travel commission. Madrid, 2009.

[6] E.J. McCharty, Basic Marketing: A Managerial Approach -(1964), 32-65 p.

[7] H. Meffert, Marketing: Grundlagen marktorientierter Unternehmensführung, 9th. ed. Wiesbaden (Ger.)-(2000), 365 p.

[8] D. Chaffey, F. Ellis-Chadwick, R. Mayer, K. Johnston, Internet Marketing: Strategy, Implementation and Practice. Pearson Education, 2006.

[9] Ye. I. Boyev, Reklama kak sotsiokul'turnoye yavleniye v sisteme sotsial'noy kommunikatsii : avtoref. dis. kand. sotsiol. nauk / Yevgeniy Ivanovch Boyev ; Kur. gos. tekhn. un-t. — Kursk, 2005. — 23 c

[10] O.U. .

[11] A. F. Mukhtasarov, Klassifikatsiya i prodvizheniye razlichnykh tipov informatsionnogo produkta metodami internet-marketinga $\mathrm{v}$ malom $\mathrm{i}$ srednem biznese // Vestnik MFYUA. 2017. №2. - s. 112-127.

[12] F.K. Kotler, Osnovy marketinga/ Kotler F.K // M: Izdatel'skiy dom «Vil'yams», 2009-356s.

[13] J. Alleman, P. Rappoport, The future of communications in Next Generation Networks. The unsus-tainability of access competition / J. Alleman and others / Document: FoV/02, January 2007. - Geneva: ITU, 2007. $-26 \mathrm{p}$.

[14] T.D. Kanishcheva, I.I. Golovaneva, N.I. Filatova, Reklama kak neot'yemlemaya chast' sovremennoy zhizni // Molodoy uchenyy. - 2014- №7347-349 s.

[15] S. Hollensen, Marketing Management: A Relationship Approach / S. Hollensen. - London : Financial Times Prentice Hall, 2010. - 698 p.

[16] M.YU. Rogozhin, Teoriya i praktika reklamnoy deyatel'nosti, M: Al'fa-Pres, 2010- 215 s.

[17] F. Breton, Vzryv kommunikatsii / F. Breton, S. Pru // Reklama: vnusheniye i manipulyatsiya. Samara : Bakhrakh-M, 2007. - S. 50-78.

[18] I.P. Berdnikov, PR - kommunikatsii. - M.: Dashkov i K, 2017-208 s.
[19] L.B. Nyurenberger, Ye.A. Karuleva, Territorial'nyye osnovy marketinga: Uchebnoye posobiye. - Novosibirsk: NGUEU, 2008. - 96

[20] M.B. Safarova, Reklama kak element marketingovykh kommunikatsiy // Ekonomika, upravleniye, finansy6 Materialy 4 Mezhdunarodnoy naunoy konferentsii - Perm': Zebra-2015,136-141s.

[21] N.V. Kononenko, Kak otsenit' effektivnost' reklamy? /Marketing i marketingovyye issledovaniya M: Libra, 2008-102 s.

[22] I.V. Moiseyenko, Klassifikatsiya metodov opredeleniya yemkosti rynka na osnove primenyayemoy marketingovoy informatsii / I.V. Moiseyenko, Ye.V. Noskova // Marketing v Rossii i za rubezhom. - 2011.- №6. - S. 23-31.

[23] Ye.I. Mazilkina, Marketing v otraslyakh i sferakh deyatel'nosti- M.: Dashkov i K, 2017. 300 s.

[24] V.O. Kononov, Internet-prodvizheniye produkta. Tendentsii razvitiya // Izvestiya RGPU im. A.I. Gertsena , 2016- 76 s.

[25] O. Otlacan, E-Marketing Strategy: 7 Dimensions to Consider (The E-Marketing Mix), (2005) -15 p.

[26] R.Ye. Mansurov, Opyt formirovaniya brenda kompanii / R.Ye. Mansurov // Marketing v Rossii i za rubezhom. - 2011.- №6. - S. 77-85.

[27] A. Pastore, M. Vemuccio, Marketing, Innovazione e Tecnologie Digitali. Una lettura in ottica sistemica, Padua (IT): Cedam, 2004- 56 p.

[28] T.A. Burtseva, Marketingovyye issledovaniya $\mathrm{V}$ sisteme informatsionnogo obespecheniya marketingovykh resheniy./ T.A. Burtseva, N.V. Nikonova.- Monografiya.-Kirov.-2004. - 249 s.

[29] R.V. Ikayeva, Reklama kak sposob sotsial'noy kommunikatsii i ob"yekt sotsial'no-filosofskogo analiza / R. V. Ikayeva // Nauchnyye problemy gumanitarnykh issledovaniy. -2012. — № 3- 32s.

[30] V.Ye. Khrutskiy, Sovremennyy marketing: nastol'naya kniga po issledovaniyu rynka. 2-izd., pererab. i dop. / V.Ye.Khrutskiy, I.V. Korneyeva. - M.: Finansy i statistika. 2002. -560 s.

[31] K.V. Kardapol'tsev, Vozmozhnosti ispol'zovaniya instrumentov internet-marketinga dlya razlichnykh otrasley natsional'noy ekonomiki / K.V. 
[44] K.G. Panin, Internet-marketing: Bannernaya reklama. - M.: Laboratoriya Knigi, 2010. - 117 s

[45] A.A. Godin, A.M.Godin, V.M.Komarov, Internet-reklama: Uchebnoye posobiye. - M.: Izdatel'sko-torgovaya korporatsiya «Danilov i $\mathrm{K}$ », 2009.- s. 67-101.

[46] G.V. Spiridonova, Internet-marketing v kommunikatsiyakh effektivnogo prodvizheniya // Vserossiyskiy zhurnal nauchnykh publikatsiy -2017. №2 (17).

[47] V.V. Tulupov, Reklama: teoriya i praktika / Tulupov V.V. - Voronezh: Izdatel'stvo VGU, 2011 $400 \mathrm{~S}$.

[48] T. Kegler, P. Douling, B.Teylor, D. Testerman, Reklama i marketing v Internete / Kegler T. - M.: Al'pina pablisher, 2003. - $640 \mathrm{~S}$

[49] U. Uells, Dzh. Bernet, S.U. Moriarti, Reklama: printsipy i praktika: Per. s angl. —SPb.: Izdatel'stvo "Piter", 1999. — 736 s.

[50] T.V. Tselyutina, A.A. Podvigaylo, Ye.V. Mal'kov, Marketingovoye targetirovaniye kak algoritm upravleniya rynochnoy uspeshnost'yu regional'nykh predpriyatiy // Sovremennyye problemy nauki i obrazovaniya. - 2014. - № 6 .

[51] Polozheniye OOH-reklamy v sisteme koordinat mirovogo mediarynka. URL: http: //out-ofhome.ua/ooh-and-the-global-ad-economy

[38] K.H. Khershgen, Marketing: osnovy professional'nogo uspekha / KH. Khershgen; per. s nem. M.: INFRA-M, 2000. - 324 s.

[39] S.YU. Tyurina, O ponyatiyakh reklamnyy diskurs i reklamnyy tekst / S. YU. Tyurina // Vestnik IGEU. - Vyp. № 1. - 2009. - S. 2-4.

[40] I.S. Doskova, PR: teoriya i praktika. - M.: Al'fa-Press, 2004. - $152 \mathrm{~s}$

[41] A. Krylov, O. Zuyenkova, Reklamnaya strategiya postanovki zadachi i otsenki effektivnosti // Rynok reklamy. - 2006. — № 5.

[42] A. Smirnov, Lidovoye poboishche. Marketingovyye instrumenty dlya prodvizheniya biznesa v Internete / A. Smirnov, YU. Suzdal'. - SPb.: IG Ves', 2015. - 176 c.

[43] P. Alashkin, Vse o reklame i prodvizhenii v Internete. - M.: Al'pina Biznes Buks, 2009. - 219 s. 